\title{
Uji efek ekstrak daun sirih hutan (Piper aduncum L.) terhadap kadar gula darah pada tikus wistar (Rattus novergicus) yang diinduksi aloksan
}

\author{
${ }^{1}$ Silvia R. H. Sitinjak \\ ${ }^{2}$ Jane Wuisan \\ ${ }^{3}$ Christi Mambo
}

\author{
${ }^{1}$ Kandidat Skripsi Fakultas Kedokteran Universitas Sam Ratulangi Manado \\ ${ }^{2}$ Bagian Farmakologi dan Terapi Fakultas Kedokteran Universitas Sam Ratulangi Manado \\ Email: silvia01sitinjak@gmail.com
}

\begin{abstract}
Forest betel leaf (Piper aduncum L.) has been known bypublicto have efficacy in wound healing, stop vomiting, reducing nausea, aiding digestion, as an antiseptic, as well as killing bacteria, fungi and viruses. Dewi et al. found that $50 \mathrm{mg} / \mathrm{kgBW}$ and $100 \mathrm{mg} / \mathrm{kgBW}$ red betel leaf extract caused a decrease blood glucose levels in Wistar rats (Rattus norvegicus) induced by alloxan. This study was aimed to identify the effect of forest betel leaf extract on blood glucose levels on Wistar rats induced by alloxan. Subjects were Wistar rats with total of 15 samples divided into five groups: a negative control group and four hyperglycemic groups induced by $130 \mathrm{mg} / \mathrm{kgBW}$ of alloxan. Forest betel leaf extract was administered with dose of $25 \mathrm{mg} / \mathrm{kgBW}, 50 \mathrm{mg} / \mathrm{kgBW}$, and $100 \mathrm{mg} / \mathrm{kgBW}$ on each groups of hyperglycemic rats, and group $0.4 \mathrm{IU} / 100 \mathrm{grBW}$ of novomix injection was administered on the positive control group. Blood glucose levels were measured in the 0,30,60, 90, and 120 minutes on day one, two, and three. The results showed that $25 \mathrm{mg} / \mathrm{kgBW}, 50 \mathrm{mg} / \mathrm{kgBW}$, and $100 \mathrm{mg} / \mathrm{kgBW}$ of forest betel leaf extract had a tendency to decrease blood glucose levels of Wistar rats induced by alloxan.
\end{abstract}

Keywords: piper aduncum L., forest betel leaf, blood glucose levels, alloxan

\begin{abstract}
Abstrak: Daun sirih hutan (Piper aduncum L.) telah dikenal oleh masyarakat dan mempunyai khasiat dalam penyembuhan luka, menghentikan muntah, mengurangi mual, melancarkan pencernaan, sebagai antiseptik, membunuh bakteri dan jamur serta virus. Menurut penelitian Dewi dkk, pemberian ekstrak daun sirih merah dengan dosis 50 $\mathrm{mg} / \mathrm{kgBB}$ dan $100 \mathrm{mg} / \mathrm{kgBB}$ menyebabkan penurunan kadar gula darah pada tikus Wistar (Rattus norvegicus) yang diinduksi dengan aloksan. Penelitian ini bertujuan untuk mengetahui efek ekstrak daun sirih hutan terhadap kadar gula darah pada tikus Wistar yang diinduksi dengan aloksan. Subjek penelitian berupa tikus Wistar berjumlah 15 ekor yang dibagi dalam 5 kelompok terdiri atas kelompok kontrol negatif dan 4 kelompok tikus Wistar yang diberi aloksan dengan dosis $130 \mathrm{mg} / \mathrm{kgBB}$ tikus yang menyebabkan tikus Wistar dalam keadaan hiperglikemik. Tikus hiperglikemik diberi ekstrak daun sirih hutan dengan dosis 25 $\mathrm{mg} / \mathrm{kgBB}$ tikus, $50 \mathrm{mg} / \mathrm{kgBB}$ tikus, dan $100 \mathrm{mg} / \mathrm{kgBB}$ tikus, dan yang terakhir kelompok kontrol positif diberi suntikan novomix 0,4 IU/100grBB tikus. Data diperoleh dari pemeriksaan kadar gula darah pada semua kelompok pada hari pertama, kedua, dan ketiga pada menit ke-0, 30, 60, 90, dan 120. Hasil penelitian menunjukkan bahwa pemberian ekstrak daun sirih hutan dengan dosis $25 \mathrm{mg} / \mathrm{kgBB}$ tikus, $50 \mathrm{mg} / \mathrm{kgBB}$ dan $100 \mathrm{mg} / \mathrm{kgBB}$ tikus memiliki kecenderungan untuk menurunkan kadar gula darah tikus Wistar yang diinduksi oleh aloksan.
\end{abstract}

Kata kunci: piper aduncumL., daun sirih hutan, kadar gula darah, aloksan 
Diabetes melitus (DM) adalah suatu penyakit metabolik dengan karakteristik hiperglikemia yang terjadi karena kelainan sekresi insulin, kerja insulin, atau keduaduanya. ${ }^{1,2} \mathrm{DM}$ merupakan penyakit kronis yang masih menjadi masalah utama dalam kesehatan di Indonesia. ${ }^{3}$

Hasil Riset Kesehatan Dasar tahun 2013 menyatakan prevalensi diabetes yang terdiagnosis dokter tertinggi terdapat di DI Yogyakarta (2,6\%), DKI Jakarta $(2,5 \%)$, Sulawesi Utara $(2,4 \%)$ dan Kalimantan Timur $(2,3 \%){ }^{4} \quad$ Menurut penelitian epidemiologi yang dilaksanakan di Indonesia, prevalensi diabetes di Manado adalah sebesar $6 \%{ }^{5}$

Tumbuhan sebagai obat-obatan tradisional merupakan tumbuhan yang diketahui dan dipercaya masyarakat, mempunyai khasiat obat dan telah digunakan sebagai bahan baku obat tradisional. ${ }^{6}$ Obat tradisional Indonesia merupakan warisan budaya bangsa sehingga perlu dilestarikan, diteliti dan dikembangkan.

Daun sirih hutan (Piper aduncum L.) telah dikenal oleh masyarakat dan mempunyai khasiat dalam penyembuhan luka, menghentikan muntah, mengurangi mual, melancarkan pencernaan, sebagai antiseptik, membunuh bakteri dan jamur serta virus. ${ }^{8}$ Penelitian Dewi et al. menunjukkan pemberian ekstrak daun sirih merah dengan dosis $50 \mathrm{mg} / \mathrm{kgBB}$ dan 100 $\mathrm{mg} / \mathrm{kgBB}$ menyebabkan penurunan kadar gula darah pada tikus Wistar yang diinduksi dengan aloksan. ${ }^{9}$ Berdasarkan informasi diatas, penulis mersa tertarik untuk mengetahui apakah ekstrak daun sirih hutan (Piper aduncum L.) berefek terhadap kadar gula darah pada tikus Wistar (Rattus norvegicus) yang diinduksi aloksan.

\section{METODE PENELITIAN}

Penelitian ini menggunakan metode eksperimental yang dilakukan di Laboratorium Fitokimia dan Laboratorium Farmakologi FMIPA Universitas Sam Ratulangi. Subyek penelitian terdiri dari 15 ekor tikus Wistar (Rattus norvegicus) dengan berat badan rata-rata $100 \mathrm{gr}$.

\section{Alat dan Bahan Penelitian}

Alat yang digunakan dalam penelitian ini terdiri dari wadah makanan, botol minuman, wadah plastik, kawat kasa, blender, oven, toples, corong, batang pengaduk, vacuum rotary evaporator, timbangan analitik, gelas ukur, cawan petri, kertas saring dr. Watts no. 1, Multi Monitoring System Autocheck, gunting minor set, sonde lambung, disposable syringe $1 \mathrm{cc}$. Bahan yang digunakan dalam penelitian ini adalah daun sirih hutan (Piper aduncum L.) (Gambar 1), aquades, $\mathrm{NaCl} 0,9 \%$, CMC 1\%, aloksan, novomix, pakan AD2, etanol 96\%, alkohol 70\%.

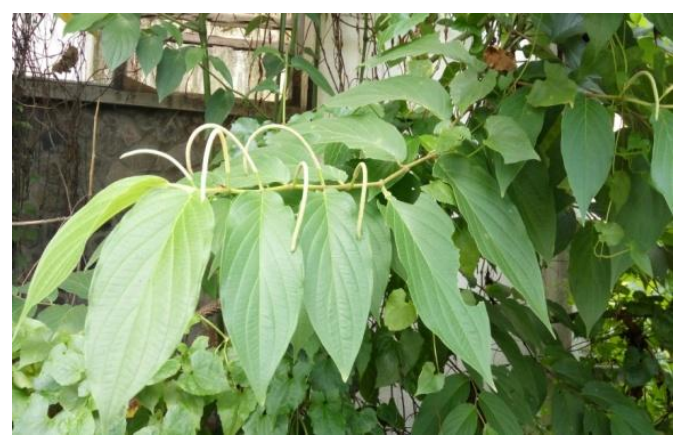

Gambar 1. Daun Piper aduncum L.

Tikus Wistar dipelihara sebanyak 15 ekor dalam keadaan sehat di dalam kandang yang diberi sekam padi. Selama satu minggu dipelihara tanpa perlakuan agar tidak stres. Tikus Wistar diberi makan pakan AD2 sebanyak 10 gr/hari dan minum dari botol yang diberi pipet.

Pada penelitian ini digunakan aloksan dengan dosis $130 \mathrm{mg} / \mathrm{kgBB} .{ }^{10}$ Tikus Wistar diberi aloksan secara intraperitoneal dengan menggunakan disposable syringe 1 cc.

Dosis insulin yang digunakan untuk manusia dengan berat badan rata-rata $60 \mathrm{~kg}$ dan kadar gula darah puasa > $180 \mathrm{mg} / \mathrm{dl}$ adalah 6 IU Novomix, ${ }^{11}$ maka dosis yang digunakan pada tikus adalah:

$$
\frac{6 \mathrm{IU}}{60 \mathrm{~kg}}=0,1 \mathrm{IU} / \mathrm{kg} \text {. }
$$

Perhitungan pemberian dosis berdasarkan pada rumus Human Equivalent Dose (HED) based on Body Surface Area (BSA), ${ }^{12,13}$ maka didapatkan hasil: 


$$
\begin{aligned}
& \text { HED }(\mathrm{mg} / \mathrm{kg})=\text { Dosis hewan }(\mathrm{mg} / \mathrm{kg}) \times \frac{\text { faktorkmhewan }}{\text { faktor km manusia }} \\
& \begin{aligned}
\text { Dosis hewan }(\mathrm{mg} / \mathrm{kg})=\operatorname{HED}(\mathrm{mg} / \mathrm{kg}) \times \frac{\text { faktorkmmanusia }}{\text { faktor } \text { km hewan }} \\
=0,1 \times \frac{37}{6}=0,61 \text { dibulatkan } 0,6 \mathrm{IU} / 150 \mathrm{grBB} \text { tikus. }
\end{aligned}
\end{aligned}
$$

Jadi, dosis insulin yang akan diberikan untuk 100grBB adalah 0,4 IU/100grBB tikus. Analog insulin diberikan secara subkutan.

Ekstrak daun sirih hutan dibuat dengan proses maserasi menggunakan etanol $96 \%$. Dosis ekstrak daun sirih hutan ditentukan yaitu $25 \mathrm{mg} / \mathrm{kgBB} / \mathrm{tikus}, 50 \mathrm{mg} / \mathrm{kgBB} /$ tikus, dan $100 \mathrm{mg} / \mathrm{kgBB} /$ tikus. $^{9}$

Lima belas ekor tikus Wistar, diadaptasi selama 1 minggu dan dibagi dalam 5 kelompok yang terdiri masingmasing atas 3 ekor. Sebelum pengukuran pada hari pertama, semua tikus dipuasakan selama 24 jam. Pada hari pertama, diperiksa kadar gula darah puasa pada masing-masing kelompok.

Hewan uji kemudian diberikan aloksan secara intraperitonial pada setiap kelompok kecuali kelompok kontrol negatif yang hanya diberikan aquades. Pada hari kedua atau 24 jam setelah pemberian aloksan, kadar gula darah tikus diukur kembali pada masing-masing kelompok. Pada hari ketiga atau 48 jam setelah pemberian aloksan, kadar gula darah tikus diukur kembali pada masing-masing kelompok lalu diberikan perlakuan pada masing-masing kelompok sebagai berikut:

1. Kelompok 1 sebagai kontrol negatif hanya diberikan aquades

2. Kelompok 2 sebagai kontrol positif diberikan suntikan novomix 0,4 IU/100grBB tikus.

3. Kelompok 3 sebagai perlakuan 1 diberikan ekstrak daun sirih hutan dengan dosis 2,5 mg/100grBB tikus.

4. Kelompok 4 sebagai perlakuan 2 diberikan ekstrak daun sirih hutan dengan dosis $5 \mathrm{mg} / 100 \mathrm{grBB}$ tikus.

5. Kelompok 5 sebagai perlakuan 3 diberikan ekstrak daun sirih hutan dengan dosis $10 \mathrm{mg} / 100 \mathrm{grBB}$ tikus.

Kadar gula darah semua tikus pada masing-masing kelompok kemudian diperiksa pada menit ke 0,30, 60, 90, dan 120. Sampel darah diambil dari ujung ekor tikus yang dipotong menggunakan gunting minor set dan diukur dengan menggunakan Multi Monitoring System Autocheck.

\section{HASIL PENELITIAN}

Rerata kadar glukosa darah kelompok kontrol negatif yang hanya diberikan aquades pada hari pertama (H1)78,67 $\mathrm{mg} / \mathrm{dl}$ menjadi $115,33 \mathrm{mg} / \mathrm{dl}$ pada hari kedua $(\mathrm{H} 2)$, selanjutnya pada hari ketiga $(\mathrm{H} 3)$ menjadi $108 \mathrm{mg} / \mathrm{dl}$, pada H3menit ke-0 menjadi 110,33 mg/dl, menit ke-30 115,33 $\mathrm{mg} / \mathrm{dl}$, menit ke-60 100,67 mg/dl, menit ke90 116,33 mg/dl dan pada menit ke-120 menjadi $118,67 \mathrm{mg} / \mathrm{dl}$.

Rerata kadar glukosa darah kelompokkontrol positif yang diberikan suntikan aloksan dan suntikan novomix, pada hari pertama (H1)67,67 $\mathrm{mg} / \mathrm{dl}$ menjadi 140,33 mg/dl pada hari kedua $(\mathrm{H} 2)$ atau 24 jam setelah disuntik aloksan, selanjutnya pada hari ketiga (H3) atau 48 jam setelah disuntik aloksan menjadi 218,33 mg/dl, pada H3 setelah diberi suntikan novomix menit ke-0 menjadi 206,33 mg/dl, menit ke-30 menjadi 145,33 $\mathrm{mg} / \mathrm{dl}$, menit ke-60 menjadi 127,33 mg/dl, menit ke-90 menjadi $80,33 \mathrm{mg} / \mathrm{dl}$, dan menit ke-120 menjadi $71 \mathrm{mg} / \mathrm{dl}$.

Rerata kadar glukosa darah kelompokperlakuan 1 yang diberikan suntikan aloksan dan ekstrak daun sirih hutan 2,5 mg/100grBB tikus, pada hari pertama (H1) 75,67 mg/dl menjadi 119,33 $\mathrm{mg} / \mathrm{dl}$ pada hari kedua (H2) atau 24 jam setelah disuntik aloksan, selanjutnya pada hari ketiga (H3) atau 48 jam setelah disuntik aloksan menjadi $127 \mathrm{mg} / \mathrm{dl}$, pada H3 setelah diberi ekstrak daun sirih hutan 
menit ke-0 menjadi $112,33 \mathrm{mg} / \mathrm{dl}$, menit ke-30 menjadi 98,33 mg/dl, menit ke-60 menjadi $106,33 \mathrm{mg} / \mathrm{dl}$, menit ke-90 menjadi $111 \mathrm{mg} / \mathrm{dl}$, dan menit ke-120 menjadi 122 $\mathrm{mg} / \mathrm{dl}$.

Rerata kadar glukosa darah kelompokperlakuan 2 yang diberikan suntikan aloksan dan ekstrak daun sirih hutan $5 \mathrm{mg} / 100 \mathrm{grBB}$ tikus, pada hari pertama (H1) $77,67 \mathrm{mg} / \mathrm{dl}$ menjadi 146,67 $\mathrm{mg} / \mathrm{dl}$ pada hari kedua $(\mathrm{H} 2)$ atau 24 jam setelah disuntik aloksan, selanjutnya pada hari ketiga (H3) atau 48 jam setelah disuntik aloksan menjadi 149,33 mg/dl, pada H3 setelah diberi ekstrak daun sirih hutan menit ke-0 menjadi $120,67 \mathrm{mg} / \mathrm{dl}$, menit ke-30 menjadi $127,67 \mathrm{mg} / \mathrm{dl}$, menit ke-60 menjadi 140,67 mg/dl, menit ke-90 menjadi $118,67 \mathrm{mg} / \mathrm{dl}$, dan menit ke-120 menjadi $124,33 \mathrm{mg} / \mathrm{dl}$.
Rerata kadar glukosa darah kelompokperlakuan 3 yang diberikan suntikan aloksan dan ekstrak daun sirih hutan $10 \mathrm{mg} / 100 \mathrm{grBB}$ tikus, pada hari pertama (H1) 65,33 mg/dl menjadi 156 $\mathrm{mg} / \mathrm{dl}$ pada hari kedua (H2) atau 24 jam setelah disuntik aloksan, selanjutnya pada hari ketiga (H3) atau 48 jam setelah disuntik aloksan menjadi 203,33 mg/dl, pada H3 setelah diberi ekstrak daun sirih hutan menit ke- 0 menjadi $135 \mathrm{mg} / \mathrm{dl}$, menit ke-30 menjadi $120 \mathrm{mg} / \mathrm{dl}$, menit ke-60 menjadi $126,33 \mathrm{mg} / \mathrm{dl}$, menit ke-90 menjadi $86,67 \mathrm{mg} / \mathrm{dl}$, dan menit ke-120 menjadi $129,67 \mathrm{mg} / \mathrm{dl}$.

Hasil pengukuran seluruh kelompok dapat dilihat pada Tabel 1 dan grafik rerata kadar gula darah seluruh kelompok dapat dilihat pada Gambar 2.

Tabel 1. Kadar gula darah seluruh kelompok

\begin{tabular}{|c|c|c|c|c|c|c|c|c|c|}
\hline \multirow{2}{*}{ Kelompok } & \multirow{2}{*}{ Hewan uji } & \multirow{2}{*}{$\begin{array}{c}\mathrm{H} 1 \\
(\mathrm{mg} / \mathrm{dl})\end{array}$} & \multirow{2}{*}{$\begin{array}{c}\mathrm{H} 2 \\
(\mathrm{mg} / \mathrm{dl})\end{array}$} & \multirow{2}{*}{$\begin{array}{c}\mathrm{H} 3 \\
(\mathrm{mg} / \mathrm{dl})\end{array}$} & \multicolumn{5}{|c|}{$\mathrm{H} 3(\mathrm{mg} / \mathrm{dl})$} \\
\hline & & & & & $\overline{0^{\prime}}$ & $30^{\prime}$ & $60^{\prime}$ & $90^{\prime}$ & $120^{\prime}$ \\
\hline \multirow{4}{*}{$\begin{array}{l}\text { Kontrol } \\
\text { Negatif }\end{array}$} & Tikus N1 & 73 & 116 & 95 & 89 & 116 & 92 & 114 & 124 \\
\hline & Tikus N2 & 78 & 99 & 101 & 116 & 124 & 107 & 118 & 120 \\
\hline & Tikus N3 & 85 & 131 & 128 & 126 & 106 & 103 & 117 & 112 \\
\hline & Rerata & 78,67 & 115,33 & 108 & 110,33 & 115,33 & 100,67 & 116,33 & 118,67 \\
\hline \multirow{4}{*}{$\begin{array}{l}\text { Kontrol } \\
\text { Positif }\end{array}$} & Tikus P1 & 65 & 136 & 205 & 195 & 134 & 122 & 61 & 46 \\
\hline & Tikus P2 & 58 & 130 & 185 & 176 & 145 & 136 & 78 & 92 \\
\hline & Tikus P3 & 80 & 155 & 265 & 248 & 157 & 124 & 102 & 75 \\
\hline & Rerata & 67,67 & 140,33 & 218,33 & 206,33 & 145,33 & 127,33 & 80,33 & 71 \\
\hline \multirow{4}{*}{$\begin{array}{c}\text { Perlakuan } \\
1\end{array}$} & Tikus A1 & 78 & 117 & 120 & 109 & 103 & 103 & 130 & 119 \\
\hline & Tikus A2 & 71 & 120 & 127 & 121 & 119 & 106 & 80 & 126 \\
\hline & Tikus A3 & 78 & 121 & 134 & 107 & 73 & 110 & 123 & 121 \\
\hline & Rerata & 75,67 & 119,33 & 127 & 112,33 & 98,33 & 106,33 & 111 & 122 \\
\hline \multirow{4}{*}{$\begin{array}{c}\text { Perlakuan } \\
2\end{array}$} & Tikus B1 & 77 & 129 & 109 & 131 & 142 & 138 & 125 & 154 \\
\hline & Tikus B2 & 82 & 126 & 136 & 124 & 116 & 125 & 108 & 91 \\
\hline & Tikus B3 & 74 & 185 & 203 & 107 & 125 & 159 & 123 & 128 \\
\hline & Rerata & 77,67 & 146,67 & 149,33 & 120,67 & 127,67 & 140,67 & 118,67 & 124,33 \\
\hline \multirow{4}{*}{$\begin{array}{c}\text { Perlakuan } \\
3\end{array}$} & Tikus C1 & 70 & 205 & 255 & 155 & 116 & 139 & 89 & 134 \\
\hline & Tikus C2 & 61 & 138 & 185 & 135 & 127 & 116 & 99 & 135 \\
\hline & Tikus C3 & 65 & 125 & 170 & 115 & 117 & 124 & 72 & 120 \\
\hline & Rerata & 65,33 & 156 & 203,33 & 135 & 120 & 126,33 & 86,67 & 129,67 \\
\hline
\end{tabular}




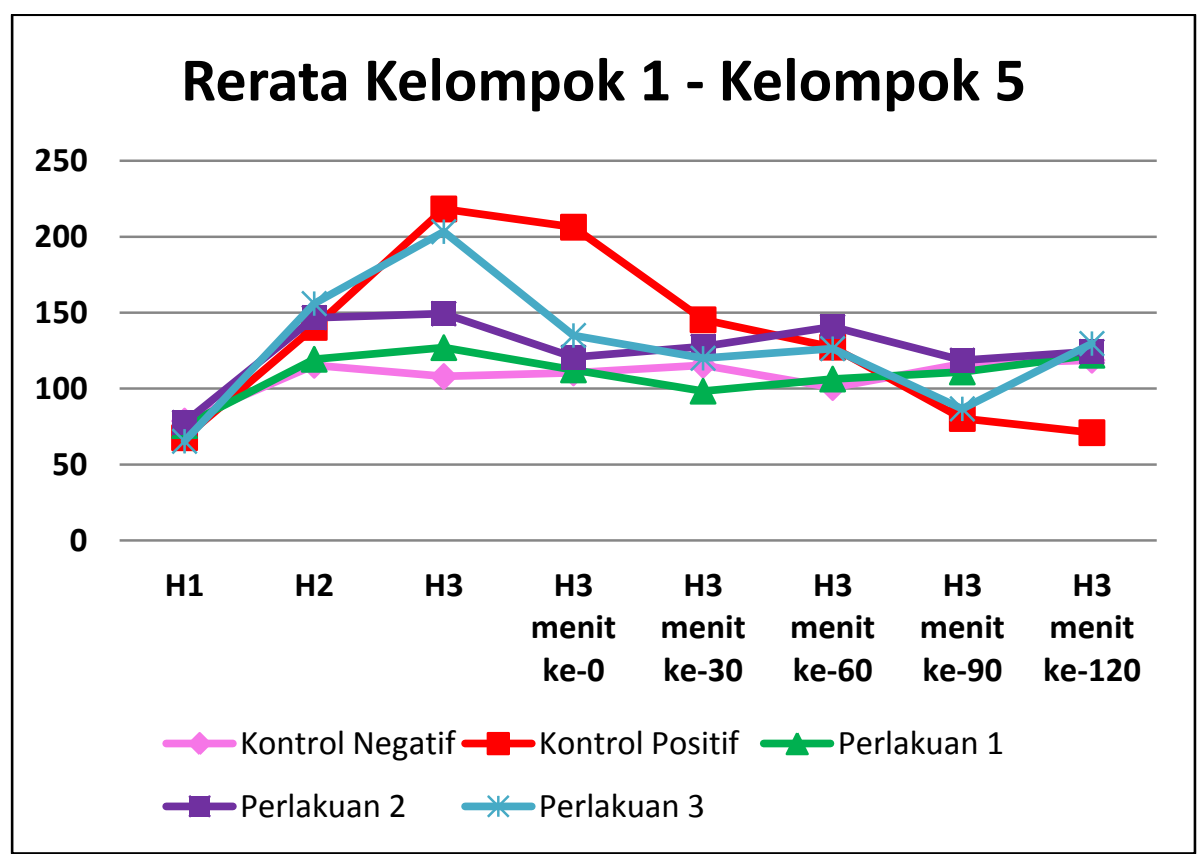

Gambar 2. Kurva kadar gula darah tikus Wistar kontrol negatif aquades, kontrol positif Novomix 0,4 IU/100 grBB, ekstrak daun sirih hutan 2,5 mg/100 grBB, ekstrak daun sirih hutan 5 $\mathrm{mg} / 100 \mathrm{grBB}$ dan ekstrak daun sirih hutan $10 \mathrm{mg} / 100 \mathrm{grBB}$.

\section{BAHASAN}

Penelitian ini dilakukan bertujuan untuk mengetahui pengaruh pemberian ekstrak daun sirih hutan terhadap penurunan kadar gula darah tikus Wistar yang diinduksi dengan aloksan.

Hasil pengukuran kadar gula darah tikus pada kelompok kontrol negatif yang hanya diberikan aquades tidak menunjukkan adanya peningkatan atau penurunan kadar gula darah yang bermakna. Hasil rerata kadar gula darah tikus pada kelompok kontrol negatif sejak hari kedua sampai hari ketiga menit ke-120 masih dalam batas normal yaitu 50-135 $\mathrm{mg} / \mathrm{dl} .{ }^{14}$ Hal ini dikarenakan tikus pada kelompok kontrol negatif hanya diberikan aquades dimana aquades merupakan air murni yang hampir tidak mengandung mineral sehingga tidak bisa untuk meningkatkan gula darah pada tikus.

Hasil pengukuran kadar gula darah tikus pada kelompok kontrol positif yang diberikan suntikan aloksan didapatkan peningkatan kadar gula darah pada hari kedua sampai hari ketiga. Pada hari kedua atau 24 jam setelah pemberian aloksan, kadar gula darah tikus pada kelompok kontrol positif mengalami peningkatan. Hal ini dikarenakan senyawa aloksan merupakan salah satu zat diabetogenik yang bersifat toksik, terutama pada sel beta pankreas dan apabila diberikan kepada hewan coba, hewan coba tersebut menjadi hiperglikemia. ${ }^{10}$ Pada hari ketiga atau 48 jam setelah pemberian aloksan, kadar gula darah tikus pada kelompok kontrol positif mengalami peningkatan yang drastis, hal ini dikarenakan aloksan menimbulkan keadaan hiperglikemia permanen dalam waktu 2-3 hari. $^{9}$ Keadaan hiperglikemia berasal dari perubahan di beberapa jalursalah satunya yaitu terjadi ketidakseimbangan antara produksi dan eliminasi ROS (Reactive Oxygen Species), dan stres oksidatif memainkan peran sentral dalam semua ini dan dapat memperparah kerusakan sel beta pankreas. ${ }^{15}$ Stres oksidatif meningkat menyebabkan aktivitas glukokinase dan biosintesis insulin menurun sehingga sekresi insulin menurun. ${ }^{15,16}$

Kelompok kontrol positif yang diberikan novomix pada hari ketiga mengalami penurunan kadar gula darah 
mulai dari menit ke-0 hingga menit ke-120. Novomix diberikan secara subkutan. Pemberian novomix menunjukkan respon yang positif dimana terjadi penurunan kadar gula darah yang bermakna. Hal ini dikarenakan novomix berkaitan dengan reseptor insulin yang meningkatkan ambilan glukosa darah dan menghambat pengeluaran glukosa oleh hepar. Novomix mulai bekerja 10-20 menit setelah diinjeksi dan memiliki efek maksimum 1-4 jam setelah diinjeksi. Durasi atau lama kerja novomix yaitu kurang dari 24 jam. $^{11}$

Pada kelompok perlakuan 1 yang diberikan ekstrak daun sirih hutan dosis 2,5 $\mathrm{mg} / 100 \mathrm{grBB}$ tikus memiliki hasil penurunan yang lebih besar pada menit ke30 , sedangkan kelompok perlakuan 2 yang diberikan ekstrak daun sirih hutan dosis 5 $\mathrm{mg} / 100 \mathrm{grBB}$ tikus memiliki hasil penurunan yang lebih besar pada menit ke90. Pada kelompok perlakuan 3 yang diberikan ekstrak daun sirih hutan dosis 10 $\mathrm{mg} / 100 \mathrm{grBB}$ tikus memiliki hasil penurunan yang lebih besar pada menit ke90 dan ini merupakan hasil penurunan yang lebih baik jika dibandingkan dengan dosis 2,5 mg/100grBB tikus dan dosis 5 $\mathrm{mg} / 100 \mathrm{grBB}$ tikus. Namun demikian, hampir semua tikus kelompok perlakuan yang diberikan ekstrak daun sirih hutan mengalami peningkatan kadar gula darah pada menit ke-120. Hal ini kemungkinan disebabkan karena ekstrak daun sirih hutan sudah tidak memiliki efek untuk menurunkan kadar gula darah. Efek penurunan kadar gula darah yang berbeda pada tiap dosis kemungkinan dipengaruhi oleh jumlah kandungan kimia yang berbeda pada tiap dosis pemberian.

Penurunan kadar gula darah pada kelompok perlakuan terjadi karena pemberian ekstrak daun sirih hutan. Dalam daun sirih hutan ada kandungan antioksidan berupa flavonoid dan polifenol yang kemungkinan merupakan penyebab turunnya kadar gula darah tikus. ${ }^{17}$ Flavonoid adalah salah satu senyawa yang mengandung antioksidan yang dapat bertindak sebagai penangkap radikal hidroksil. ${ }^{9} \quad$ Polifenol adalah salah satu antioksidan yang mampu mengurangi stres oksidatif dengan cara mencegah terjadinya reaksi berantai pengubahan superoksida menjadi hidrogen superoksida dengan mendonorkan atom hidrogen dari kelompok aromatik hidroksil (-OH) polifenol untuk mengikat radikal bebas dan membuangnya dari dalam tubuh melalui sistem ekskresi. ${ }^{18}$ Peran polifenol sebagai antioksidan diduga mampu melindungi sel beta pankreas dari efek toksik radikal bebas, mengurangi stres oksidatif, dan menurunkan ekspresi TNF- $\alpha{ }^{18,19}$

\section{SIMPULAN DAN SARAN}

Berdasarkan hasil penelitian ini dapat disimpulkan bahwa ekstrak daun sirih hutan dengan dosis $25 \mathrm{mg} / \mathrm{kgBB}$ tikus, 50 $\mathrm{mg} / \mathrm{kgBB}$ dan $100 \mathrm{mg} / \mathrm{kgBB}$ tikus memiliki kecenderungan untuk menurunkan kadar gula darah tikus Wistar yang diinduksi oleh aloksan.

Berdasarkan hasil penelitian ini maka perlu dilakukan penelitian lebih lanjut mengenai kandungan kimia yang mempunyai efek menurunkan kadar gula darah, mengenai efek samping dari daun sirih hutan serta menggunakan hewan uji yang lebih banyak.

\section{DAFTAR PUSTAKA}

1. Purnamasari D. Diagnosis dan Klasifikasi Diabetes Melitus. Dalam: Sudoyo AW, Setiyo HB, Alwi I, Simadibrata M, Setiati S. Buku Ajar Ilmu Penyakit Dalam. Edisi ke-5. Jakarta Pusat: Interna Publishing; 2009. h. 1880-3.

2. Priantono D, Sulistianingsih DP. Diabetes Melitus. Dalam: Tanto C, Liwang F, Hanifati S, Pradipta EA. Kapita Selekta Kedokteran. Edisi ke-4. Jakarta: Media Aesculapius; 2014. h. 777-9.

3. Yuliani F, Oenzil F, Iryani D. Hubungan berbagai Faktor Risiko terhadap Kejadian Penyakit Jantung Koroner pada Penderita Diabetes Melitus Tipe 2. Jurnal Kesehatan Andalas. 2014;3:37.

4. Departemen Kesehatan RI. Riset Kesehatan Dasar (RISKESDAS) 2013. Jakarta: 
Badan Penelitian dan Pengembangan Kesehatan; 2013. h. 87-90.

5. Suyono S. Diabetes Melitus di Indonesia. Dalam: Sudoyo AW, Setiyo HB, Alwi I, Simadibrata M, Setiati S. Buku Ajar Ilmu Penyakit Dalam. Edisi ke-5. Jakarta Pusat: Interna Publishing; 2009. h. 1874-8.

6. Yuniati E, Alwi M. Etnobotani Keanekaragaman Jenis Tumbuhan Obat Tradisional dari Hutan di Desa Pakuli Kecamatan Gumbasa Kabupaten Donggala, Sulawesi Tengah. Biocelebes. 2010;4:69.

7. Dewoto HR. Pengembangan Obat Tradisional Indonesia menjadi Fitofarmaka. Maj Kedokt Indon. 2007;57:205-6.

8. Gholib D. Uji Daya Hambat Ekstrak Etanol Daun Karuk (Piper sarmentosum ROXB.) dan Daun Seserehan (Piper aduncum L.) terhadap Trichophyton mentagrophytes. Seminar Nasional Teknologi Peternakan dan Veteriner; Bogor: 2009.

9. Dewi YF, Anthara MS, Dharmayudha GO. Efektifitas Ekstrak Daun Sirih Merah (Piper crocatum) terhadap Penurunan Kadar Glukosa Darah Tikus Putih Jantan (Rattus norvegicus) yang di Induksi Aloksan. Buletin Veteriner Udayana. 2014;6:73-9.

10.Nugroho AE. Hewan Percobaan Diabetes Melitus: Patologi dan Mekanisme Aksi Diabetogenik. Biodiversitas. 2006; 7:378-82.

11.Anonim. NovoMix, INN-insulin Aspart. [Internet] [Diakses pada tanggal 29 September 2016]. Tersedia di:http://www.ema.europa.eu/docs/en _GB/document_library/EPAR__Product_Information/human/000308
/WC500029441.pdf

12.Shin JW, Seol IC, Son CG. Interpretation of Animal Dose and Human Equivalent Dose for Drug Development. The Journal of Korean Oriental Medicine. 2010;31:1-7.

13.Parvova I, Danchev N, Hristov E. Animal Models of Human Diseases and Their Significance for Clinical Studies of New Drugs. J Clin Med. 2011;4:1929.

14.Johnson MD, Gad SC. The Rat. In: Gad SC. Animal Models in Toxicology. 2nd Edition. New York: Taylor \& Francis; 2007. p. 152,196.

15.Campos C. Chronic Hyperglycemia and Glucose Toxicity: Pathology and Clinical Sequelae. Postgraduate Medicine. 2012;124:2-4.

16. Kawahito S, Kitahata $H$, Oshita S. Problems Associated with Glucose Toxicity: Role of Hyperglicemiainduced Oxidative Stress. World J Gastroenterol. 2009;15:4137-40.

17.Kinho J, Arini DID, Halawane J, Nurani L, Halidah, Kafiar Y, dkk. Tumbuhan Obat Tradisional di Sulawesi Utara. Jilid II. Manado: Balai Penelitian Kehutanan Manado Badan Penelitian dan Pengembangan Kehutanan Kementrian Kehutanan; 2011. h. 34-5.

18. Ridwan A, Astrian RT, Barlian A. Pengukuran Efek Antidiabetes Polifenol (Polyphenon 60) Berdasarkan Kadar Glukosa Darah dan Histologi Pankreas Mencit (Mus musculus L.) S. W. Jantan yang di Kondisikan Diabetes Mellitus. Jurnal Matematika \& Sains. 2012;17:80-2.

Widowati W. Potensi Antioksidan sebagai Antidiabetes. JKM. 2008;7: $1-7$. 